\title{
The Learning Implementation of Writing Non-Literary Text by Online during the Covid-19 Pandemic in the Eighth Grade Students at State of Junior High School of 8 Yogyakarta
}

\author{
${ }^{* 1}$ Eva Kurniawati and ${ }^{2}$ Teguh Setiawan \\ ${ }^{* 1}$ Postgraduate, Yogyakarta State University, Indonesia, evakurniawati7474@gmail.com \\ ${ }^{2}$ Postgraduate Lecturer, Yogyakarta State University, Indonesia, teguh_setiawan@uny.ac.íd
}

Submitted: 18/03/2021

Revised: $21 / 04 / 2021$

Accepted: 13/05/2021

How to cite this article: Kurniawati, E., \& Setiawan, T. (2021). The learning implementation of writing nonliterary text by online during the covid-19 pandemic in the eighth grade students at state of junior high school of 8 Yogyakarta. IJELR: International Journal of Education, Language, and Religion, 3(1), 27-36.

\begin{abstract}
This study aims to describe the planning and implementation of learning to write non-literary texts online during the Covid-19 pandemic, the barriers in the implementation of learning, and the efforts of teachers to overcome these barriers. This research is a qualitative descriptive study. The subjects of this study were teachers and the eighth grade students in state of Junior High School of 8 Yogyakarta. The object of research is focused on planning and implementing learning to write non-literary texts, barriers, and the efforts of teachers to overcome barriers to learning online during the Covid-19 pandemic. Data obtained by observation, interview, and documentation techniques. Data analysis techniques include the stages of data reduction, data presentation, and conclusions. Based on the research conducted, it can be seen that learning planning includes syllabus and specific lesson plans for online learning, while the implementation of learning includes objectives, teaching materials, methods, media, and evaluation. Furthermore, the barriers faced by teachers include facilities and infrastructure, signal stability, and online learning design creativity. On the other hand, the barriers faced by students include signal stability, data packages, and the learning process. The teacher has a role in overcoming the barriers to online learning that occur.
\end{abstract}

Keywords

writing; non-literary text; online learning

\section{Introduction}

At the end of 2019, there was an outbreak that spread throughout the world. The Coronavirus outbreak 2019 or often known as Covid-19 is a mysterious new outbreak and originated in Wuhan, China (Zhang, Jiang, Yuan \& Tao, 2020). In fact, this corona virus has also been an outbreak in Indonesia since early March 2020.

The Covid-19 pandemic that occurred in Indonesia had a major impact on various fields, including health, economy, social, culture and education. UNESCO's response as an institution engaged in the field of education strongly approves of the learning implementation of using an online platform for distance learning efforts. It aims to make learning can be reached by students wherever they are. In addition, the most important actors in the change from learning implementation in classroom to 
learning implementation in network are teachers or educators, because they are the controllers in the learning process (Bao, 2020; Basilaia \& Kvavadze, 2020).

In the world of education in Indonesia, in order to prevent the transmission of Covid-19, the Minister of Education and Culture (Mendikbud), Nadiem Anwar Makarim issued Circular Letter Number 4 of 2020 concerning Implementation of Education in the Emergency Period of Coronavirus Disease (Covid-19). Based on Culture Circular of the Minister of Education Number 4 of 2020, all teachers and students learn from home and the teaching and learning process is replaced from face-to-face learning to online learning, to prevent the spread of Covid-19 (Purwanto, Pramono, Asbari, Santoso, Wijayanti, Hyun \& Putri, 2020). School managers, students, parents, and of course teachers must migrate to digital or online learning systems, which is better known as e-learning or known as network learning or "online learning” (Aderholt, 2020; Karp \& McGowan, 2020).

Online learning model is actually not new anymore. Not infrequently, there were teachers or lecturers who practiced it before the Covid-19 outbreak in Indonesia. However, there are mostly teachers and students in Indonesia who have just experienced this learning model. This is due to social and physical restrictions since Covid-19 penetrated all parts of Indonesia.

Teachers and students carry out distance learning or online systems using information technologybased media (Pramana, 2020; Rosali, 2020). The technology-based media in question includes cell phones, laptops or computers with the help of the internet. In this case, students must prepare some of these supporting media in order to follow a good learning process.

Apart from the media, the readiness of teachers in distance learning or online is very important. Online learning is seen as something new and a challenge for teachers. Teachers must prepare plans and carry out the learning process as good as possible even during the Covid-19 pandemic. This is in accordance with Majid (2011, p. 17), which stated that planning is the process of preparing subject matter, using teaching media, using teaching approaches and methods, and assessing an allocation of time that will be carried out at a certain time to achieve the goals that have been determined.

Based on the previous statement, the ideal online learning plan must also be guided by the applicable curriculum. Teachers are expected to be more creative and innovative to prepare online learning that attracts students' interest and enthusiasm for learning. In addition, teachers are also expected to be able to master the fields of science and technology.

Online language learning of course also requires special attention, for example in learning to write. This is also supported by Huy (2015) who argued that writing is a complex thought process activity which requires someone's knowledge, basic abilities, strategies, and the ability to coordinate a process that consists of many parts. In this case, students are expected to be able to write and produce quality writing even in online learning.

Writing can be classified into two, namely literary and non-literary writing (Yuniar \& Zuchdi, 2018). The main thing that distinguishes the two writings is the idea that underlies the writing. Based on the ideas underlying the two writings, of course there are differences in the implementation of learning to write literary texts and non-literary texts. Literary writing is based on imaginative ideas and generally aims to entertain. On the other hand, non-literary writing is based on ideas in the form of facts or opinions based on actual (real) circumstances.

In this research, the writer focused on non-literary writing that requires facts and truth in presenting ideas. Newmark (2004) described non-literary texts as a focus on the world of facts for the reader. Based on the results of his research, it showed that these texts were written using standard language to present information, generally using third person pronouns. Furthermore, the sounds of non-literary 
texts are often read quickly, and the language is easy to understand. Furthermore, Khosravishakib (2012) also observed that non-literary texts were written using standard language or language that is easy to understand. Standard language, such as that appears in non-literary texts, can help readers to understand quickly of the subject matter.

Based on the phenomena that have been described, the researchers will examine how the planning, implementation, barriers, and solutions in learning to write non-literary texts online during the Covid19 pandemic. The purpose of this study is to describe the planning, implementation, barriers, and solutions made in learning to write non-literary texts during the Covid-19 pandemic to Eighth Grade Students at State of Junior High School of 8 Yogyakarta.

\section{Method}

This type of research used in this research was a qualitative descriptive method. Sources of data in this study were Indonesian language teachers and eighth grade students at State of Junior High School of 8 Yogyakarta. The data in this study was a learning plan that includes a syllabus and a lesson plan (RPP). Furthermore, data about the implementation of learning includes learning components. The instruments used in this study were interview, observation, and documentation guidelines.

The data collection technique is an activity carried out by researchers in order to obtain the data used in the study. Data collection techniques used in this study was interviews, observations, and documentation. The type of interview used in this study was a semi-structured interview. Furthermore, observations are made when the online learning process is carried out. Furthermore, the documents used can be in the form of writings, pictures, or monumental works of a person (Sugiyono, 2014, $\mathrm{p}$. 82). The documents in this study were in the form of a syllabus, online lesson plans (RPP), the teaching materials used, media samples and assessments, as well as photos of online learning.

The data analysis technique used by the researcher was the Miles and Huberman model analysis technique. In this case, there were three processes in data analysis, namely, data reduction, data display, and conclusion drawing/verification. The process of qualitative data analysis was carried out interactively and took place continuously until it was complete so that the data was saturated and got the best results.

\section{Results}

Based on research conducted at State of Junior High School of 8 Yogyakarta, the following results can be obtained.

Table 1.Observation Result

\begin{tabular}{|c|c|}
\hline Aspects Researched & Observation Result \\
\hline \multicolumn{2}{|l|}{ Online Learning Planning } \\
\hline a. Syllabus & government-made syllabus \\
\hline b. Lesson plan (RPP) & a special lesson plan for online learning \\
\hline \multicolumn{2}{|l|}{ Implementation of Online Learning } \\
\hline a. Objective & delivered by the teacher on the perception of learning \\
\hline b. Material & $\begin{array}{l}\text { Ministry of Education and Culture's published books, private published } \\
\text { companion books, and special modules }\end{array}$ \\
\hline c. Method & project based learning and scientific learning \\
\hline d. Media & $\begin{array}{l}\text { online-based media, such as WhatsApp Group, Geschool, Zoom Meeting, } \\
\text { Google Meet, and Google Form }\end{array}$ \\
\hline e. Evaluation & daily evaluation, Mid-Term Examination (UTS), and Final Examination (UAS) \\
\hline Barriers of Online Learning & $\begin{array}{l}\text { a) Teachers: facilities and infrastructure, signal stability, and online learning } \\
\text { design creativity }\end{array}$ \\
\hline & b) Students: stability of signals, data packages, and the learning process \\
\hline $\begin{array}{l}\text { Efforts to Overcome Barriers of Online } \\
\text { Learning }\end{array}$ & $\begin{array}{l}\text { a) Teachers: improving facilities and infrastructure, improving network } \\
\text { quality, learning the world of IT, and making innovations }\end{array}$ \\
\hline & b) Students: improve network quality and communicate well with teachers \\
\hline
\end{tabular}




\section{Discussion}

\section{Online Learning Planning}

This section is also a major part of the research articles and is also usually the longest part of an article. Discussion of the research presented in this section are the result. The process of data analysis such as statistical calculations or other processes for the achievement of its research. Please present the discussion narratively.

At the end of December 2019, the world was shocked by the spread of the SARS-CoV-2 virus or the cause of the Covid-19 disease. The existence of the Covid-19 pandemic has changed the world order. It has even had various significant impacts. This can be seen from several fields, such as the health, economy, social, culture and education fields.

In the world of education in Indonesia, the government has issued a learning system policy which was originally face-to-face changed into an online system. This is based on the Circular Letter of the Minister of Education and Culture Number 4 of 2020 concerning the Implementation of Education Policies in Emergency Period of the spread of Covid-19. One of the contents is rules in the learning process from home. There were several provisions that were regulated, including the basic spirit of online learning, focus on learning from home, learning activities and assignments while learning from home, and the role of the teacher in providing feedback.

Based on the data that has been obtained in the field, it can be known that the teacher was reorganizing and preparing plans for online learning. Even during the Covid-19 condition, teachers were still preparing for online learning as much as possible. This was consistent with research conducted by Morrison, Mokashi, and Cotter (2006, p. 4-21) regarding the quality of learning. The quality of learning can be said to be good if: 1) the physical environment is able to foster students' enthusiasm for learning; 2) the classroom climate is conducive for learning; 3 ) the teacher conveys the lesson clearly and all students have the desire to succeed; 4 ) the teacher delivers lessons in a systematic and focused manner; 5) the teacher presents the material wisely; 6) learning is real (authentic to the problems faced by society and students); 7) there is a diagnostic assessment carried out periodically; 8) reading and writing as essential activities in learning; 9) using rational considerations in solving problems; and 10) using learning technology, both for teaching and student learning activities.

The planning in question includes the syllabus and the Lesson Plan (RPP). In this planning, the syllabus was used by the teacher in online learning still follows the guidelines or regulations in the face-to-face learning system. However, this was different from the Lesson Plan (RPP). The lesson plan (RPP) was used by Indonesian Language teachers at State of Junior High School of 8 Yogyakarta was a special lesson plan for online learning. The Lesson Plan (RPP) contains procedures for learning activities from the beginning to those that are in accordance with the indicators and learning objectives that have been formulated. It aims to make teaching and learning activities easier and smoother and can improve the results of the teaching and learning process. Furthermore, the teacher also adjusted it to the allocation of time, learning media, learning methods, learning materials, and even evaluation.

\section{Implementation of Online Learning}

UNESCO stated that at least 1.5 billion school-age children have been affected by Covid-19, including Indonesia (Putria, Maula, \& Uswatun, 2020). As a result of this pandemic, schools were closed. This school closure was carried out with the aim of preventing the spread of Covid-19. However, students can still study at home with an online learning system. The following is the learning implementation of writing non-literary texts online in the Covid-19 pandemic at State of Junior High School of 8 Yogyakarta. 


\section{Objective}

The learning objectives are contained in the Lesson Plan (RPP) that has been prepared by the teacher. The objectives that have been formulated by the teacher were based on the applicable curriculum and syllabus that was adapted to the conditions of the Covid-19 pandemic and the abilities of students. It is intended that learning to write non-literary texts can be well focused and directed. Even though learning online, the teacher always conveys the learning objectives to be achieved. Students are expected to achieve predetermined goals, for example to be able to create or write non-literary texts properly and in accordance with applicable regulations.

\section{Material}

Learning material is one component that supports the achievement of successful learning. The material presented in learning is in accordance with the Kemdikbud syllabus. After that, the material was adjusted to the needs and conditions of Eighth Grade at State of Junior High School of 8 Yogyakarta in the Covid-19 pandemic. These adjustments include the allocation of learning time, relevant material sources, and additional material that is deemed more important.

The learning material related to the materials and textbook sources that was used by teachers and students in the Indonesian Language learning process, especially writing non-literary texts. In this odd term, the non-literary text material in eight grade includes 1) news text;2) advertisements, posters and slogans; 3) the text of the exposition; and 4) explanatory text (Permendikbud, 2016). Students are expected to be able to hone their skills by writing non-literary texts in accordance with the Core Competencies (KI) and Basic Competencies (KD) in the Lesson Plan (RPP).

Based on the interviews that have been conducted, the teacher used learning resources such as the Ministry of Education and Culture's books, private publisher support books, and modules. The module was made personally by the teacher. The teacher made modules that have been adapted to the lesson plans and the needs of their students. The module was developed by the teacher and was distributed to students. This aims to make it easier for teachers and students to follow the learning flow. The specifications include the subject matter, a summary, and are completed with student worksheets.

\section{Method}

The learning method is one of the components that influence the success of Indonesian Language learning, including learning to write non-literary texts. Learning methods are used to increase student interest and enthusiasm in online learning during the Covid-19 pandemic. In addition, methods also have an effect in making the delivery of material easier and more effective. In delivering the material, the teacher always tries to make students feel happy in participating in the lesson so that they are able to understand the material well.

It cannot be denied that online learning has an impact on students. The impact that was experienced by students was that students felt very bored when participating in the learning process. The spirit and enthusiasm shown by the students was decreasing day by day. Therefore, the teacher tried to make innovations and some reforms in the learning process to increase students' enthusiasm for learning. Teachers at State of Junior High School of 8 Yogyakarta were also tried to conduct training or workshops related to the online learning system.

The existence of the Covid-19 pandemic requires face-to-face learning to be replaced with online learning. In learning to write non-literary texts online, eighth grade teachers used project-based learning and scientific learning. This was in accordance with Permendikbud Number 22 of 2016 concerning Basic and Secondary Education Process Standards as follows; "Selection of an integrated thematic and/or thematic approach and/or scientific and/or inquiry and discovery and/or learning that results in work based problem solving (project based learning) adjusted to the characteristics of competencies and educational levels". 
Project Based Learning (PBL) is an innovative learning that emphasizes contextual learning through complex activities. Project-based learning (PBL) can also be interpreted as learning designed for complex problems where students carry out investigations to understand them, emphasize learning with long activities, assignments given to students are multidisciplinary, and product-oriented (Nayono \& ER, 2013).

Project-based learning was used by the teacher when learning to write advertisements, posters, and slogans. Students were asked to make advertisements, posters, or slogans according to the instructions set by the teacher. Furthermore, the results of the student's work were sent to the school via package services or online motorcycle taxis.

\section{Media}

Media is one component of learning and can determine the success of learning. In this case, the media used was related to (online) network learning. Media can also be interpreted as anything that can be used to transmit messages from sender to recipient so that it can stimulate students' thoughts, feelings, attention, and interests in such a way so that a learning process occurs (Arsyad, 2005, p. 45). In addition, learning media is useful for helping teachers in delivering material and making it easier for students to understand the material.

The success of teachers in conducting online learning in the Covid-19 pandemic situation can be seen from the ability of teachers to innovate in designing, concocting materials, and learning methods. In addition, the teacher must also determine what applications are in accordance with the material and learning methods. In this phenomenon, creativity is needed. Creativity is the key to success for a teacher to be able to motivate students to stay enthusiastic about learning online and not become a psychological burden.

The learning media was used by teachers and students at State of Junior High School of 8 Yogyakarta were WhatsApp Group, Geschool, Zoom Meeting, Google Meet, and Google Form. WhatsApp Group can be interpreted as a virtual classroom that facilitates each member to communicate with fellow members regarding learning materials. WhatsApp Group users will get the influence of the communication process because it makes communication easier. WhatsApp Group is used by teachers to provide initial instructions regarding learning to be carried out. This application is also used by the teacher after learning has been completed, to provide instructions or draw conclusions.

State of Junior High School of 8 Yogyakarta collaborated with private platforms to provide applications that support learning. The application in question was Geschool. Geschool is a LMS (Learning Management System) web which has very diverse functions, from a diary, media for publication of important information, general science, and education (Sudiana, 2016). This application is often used by teachers to provide or upload material, it can even be used for practice questions.

The Zoom Meeting application can be used by teachers and students for learning to write non-literary texts face-to-face virtually. This application is considered to be able to help teachers in monitoring students' attitudes and attention to the learning that is taking place. This was supported by research conducted by Haqien and Rahman (2020), which stated that the use of Zoom Meeting is considered practical and efficient for students, because by using Zoom Meeting, communication becomes easier than communicating in writing or via chat.

Google Meet and Google Forms were also used by teachers and students for online learning. Both of these features are application services provided by Google to support the learning process. Through Google Meet, teachers and students can meet face to face virtually. Furthermore, Google Form was used for student attendance. Students are required to make presence as well as face-to-face learning in 
class. Meanwhile, Google Form also has a feature to create online exams (Hidayat, Wicaksono, Rahmatya, Lubis \& Nurhayati, 2020).

\section{Evaluation}

Learning evaluation is a process of determining the level of achievement of predetermined learning objectives in a systematic way. Learning evaluation aims to collect information that becomes the basis for measuring the level of progress, development, learning achievement of students, and the effectiveness of educators in teaching. In addition, evaluation also aims to determine whether the planning is in accordance with the implementation of learning.

In accordance with the Lesson Plan (RPP) of Indonesian Language at State of Junior High School of 8 Yogyakarta that has been made, the forms of evaluation used in learning to write non-literary texts are test and non-test. Evaluation in the form of tests can be divided into two, namely oral tests and written tests. Non-test evaluation was carried out by observing student learning behavior in the learning process. This was in accordance with Permendikbud Number 22 of 2016 concerning Basic and Secondary Education Process Standards as follows.

Evaluation of the learning process is carried out during the learning process using the following tools: observation sheets, peer questionnaires, recordings, anecdotal notes, and reflections. Evaluation of learning outcomes is carried out during the learning process and at the end of the lesson unit using methods and tools: oral/action tests, and written tests. The final evaluation results are obtained from a combination of process evaluation and evaluation of learning outcomes.

The evaluation carried out in learning to write non-literary texts can be illustrated in the daily evaluation, Mid-Term Examination (UTS), and Final Examination (UAS). In daily evaluations, using the project-based learning method, students wrote non-literary texts which will be collected to the teacher for assessment. The results of the student's writing must meet the standard assessment criteria based on the assessment indicators that have been determined by the teacher. In the Covid-19 pandemic situation, the Mid-Term Examination (UTS) and Final Examination (UAS) were still carried out online. In order to make it easier for students, the questions given were questions in the form of multiple choices. Even so, the teacher can still find out the level of understanding of students' writing of non-literary texts by comparing the grilles and answers.

\section{Barriers of Online Learning}

Learning is never separated from various barriers, especially in network (online) learning. Barriers of learning become a spur to carry out better learning. The following are learning barriers that occurred during online learning to write non-literary texts.

The barriers were felt by the teacher include facilities and infrastructure, signal stability, and online learning design creativity. First, facilities and infrastructure. Unsupportive facilities and infrastructure sometimes become barriers in the online learning process. Second, signal stability. Signal stability is an important factor in online learning. However, sometimes the network signal is erratic. This can hinder the learning process, especially when the teacher delivers learning material. Third, online learning design creativity. In this case, the teacher must be able to master the field of technology because the online learning system uses the help of information technology devices. In accordance with the research conducted by Rasheed, Kamsin, and Abdullah (2019), that teachers face the challenges of technological literacy and competence. Not infrequently, teachers experienced a lack of confidence, lack of time, and willingness to learn these new technologies (Lightner \& Lightner-Laws, 2016). Even so, teachers still have to innovate in designing online learning so that students don't feel bored.

Barriers were not only felt by the teacher, students also experienced it. The barriers that the students felt include signal stability, availability of data packages, and the learning process. The first problem is 
related to signal stability and availability of data packets. An unstable network became barriers in the learning process with an online system. Therefore, the existence of adequate network facilities can be said to be the main thing in online system learning.

The existence of students who are far from the city center or far from the reach of the provider network, of course, cannot carry out this online learning process smoothly. This was in accordance with the results of research by Rasheed, Kamsin, and Abdullah (2019) that there are some discomforts that students feel in online learning can be caused by several reasons such as personality, a sense of distance in the online environment, lack of confidence and trust in online community participants, lack of communication cues (facial expressions, tone of voice, etc.), connection difficulties (e.g. low internet speed), and poor writing skills or language barriers.

The next barrier that students experienced was the learning process. In the learning process, students felt a pile of assignments. This component was considered to be a barrier for students because students still need to adjust learning conditions with the online system. However, this will slowly improve if this online learning system is used to being carried out in the learning process, especially in writing non-literary texts.

\section{Efforts to Overcome Barriers of Online Learning}

The existence of various barriers that occurred can interfere with the implementation of learning. The teacher has a role in overcoming learning barriers. The following describes some of the efforts made by the teacher in overcoming barriers of learning to write non-literary texts online.

Efforts to overcome barriers from teachers can be done by improving facilities and infrastructure. In this case, the school provides better supporting facilities to improve the learning process. The second effort that can be done is to improve the quality of the signal network. The school improves the quality of the network for the betterment of the online learning process. Furthermore, the third effort is for teachers to learn the world of Information and Technology (IT) and make innovations. Teachers continue to make and try various new innovations and changes to support the success of online learning. Not only that, the school also conducts various trainings or workshops for teachers. With this, it is hoped that teachers can develop more in providing media and innovative learning methods.

Efforts to overcome barriers of students can be done by improving the quality of the network. Students can change the type of provider that is better or in accordance with the conditions of their home environment. The next effort is to build good communication with the teacher. In the conditions of the Covid-19 pandemic and students are required to study from home with an online system, students often complain that there are too many assignments. Therefore, good communication between teachers and students is needed. Teachers can provide understanding to students related to the conditions that they are facing. The teacher can also encourage students to always follow the learning of writing nonliterary texts well.

\section{Conclusion}

Based on the results of research and discussion of learning to write non-literary text in eighth grade students at State of Junior High School of 8 Yogyakarta, it can be concluded that learning to write nonliterary texts was in accordance with the online syllabus and Lesson Plan (RPP) during the Covid-19 pandemic. This can be seen based on the learning components which include objectives, materials, methods, media, and evaluation. In addition, there were several barriers faced by teachers and students. The barriers were faced by the teacher include facilities and infrastructure, signal stability, and online learning design creativity. On the other hand, the barriers were faced by students include signal stability, data packages, and the learning process. In this phenomenon, teachers have an important role in overcoming barriers to online learning that occurred. 


\section{References}

Aderholt, R. (2020). Coronavirus outbreak shining an even brighter light on internet disparities in rural America. The Hill.

Anggriani, W. \& Indihadi, D. (2020). Analisis rencana pelaksanaan pembelajaran dalam pembelajaran menulis narasi di SD. Pedadidaktka: Jurnal Ilmiah Pendidikan Guru Sekolah Dasar, 5(1), 1122.

Argawati, N. O. \& Suryani, L. (2020). Project-based learning in teaching writing: The implementation and students' opinion. English Review: Journal of English Education, 8(2). https://doi.org/10.25134/erjee.v8i2.2120

Arsyad, A. (2005). Media pembelajaran. Jakarta: Raja Grafindo Persada.

Bao, W. (2020). Covid-19 and online teaching in higher education: A case study of Peking University. Pedagogical Research, 5(4), 113-115. https://doi.org/https://doi.org/10/1002/he2.191

Basilaia, G. \& Kvavadze, D. (2020). Transition to online education in schools during a SARS-CoV-2 Coronavirus (Covid-19) pandemic in Georgia. Pedagogical Research, 5(4). https://doi.org/10.29333/pr/7937

Haqien, D. \& Rahman, A. A. (2020). Pemanfaatan zoom meeting untuk proses pembelajaran pada masa pandemi covid-19. SAP (Susunan Artikel Pendidikan), 5(1), 51-56. https://doi.org/10.30998/sap.v5i1.6511

Hidayat, Wicaksono, M. F., Rahmatya, M. D., Lubis, R. \& Nurhayati, S. (2020). Optimalisasi pemanfaatan aplikasi google classroom dan google form sebagai penunjang pembelajaran daring di SMA Negeri 5 Cimahi. IComSE (Indonesian Community Service and Empowerment), 1(2), 55-60. https://doi.org/10.34010/icomse.v1i2.3876

Huy, N. T. (2015). Problems affecting learning writing skill of grade 11 at Thong Linh high school. Asian Journal of Educational Research, 3(2), 53-69.

Karp, P. \& McGowan, M. (2020). "Clear as mud” schools ask for online learning help as coronavirus policy confusion persists Australia news. The Guardian.

Kemendikbud RI. (2020). Surat Edaran Nomor 4 Tahun 2020 tentang Pelaksanaan Kebijakan Pendidikan dalam Masa Darurat Penyebaran Coronavirus Disease (Covid- 19).

Khosravishakib, M. (2012). Literary and non-literary texts from viewpoint of formalism as rudimentary of other literary criticism. International Journal of Arts, 2(3), 11-15.

Lightner, C. A. \& Lightner-Laws, C. A. (2016). A blended model: Simultaneously teaching a quantitative course traditionally, online, and remotely. Interactive Learning Environments, 24(1), 224-238. https://doi.org/10.1080/10494820.2013.841262

Nayono, S. E. \& ER, N. (2013). Pengembangan model pembelajaran project based learning pada mata kuliah computer aided design. Jurnal Pendidikan Teknologi dan Kejuruan, 21(4).

Newmark, P. (2004). Non-literary in the light of literary translation. The Journal of Specialised Translation, 1, 8-13.

Majid, A. (2011). Perencanaan pembelajaran. Bandung: Remaja Rosadakarya.

Morrison, Mokashi \& Cotter. (2006). A concepts and principles for effective practice. Englewood Cliffs: Educational Technology Publications.

Peraturan Menteri Pendidikan dan Kebudayaan Republik Indonesia Nomor 65 Tahun 2013 tentang Standar Proses Pendidikan Dasar dan Menengah.

Peraturan Menteri Pendidikan dan Kebudayaan Republik Indonesia Nomor 22 Tahun 2016 tentang Standar Proses Pendidikan Dasar dan Menengah. 
Peraturan Menteri Pendidikan dan Kebudayaan Republik Indonesia Nomor 24 Tahun 2016 tentang Kompetensi Inti dan Kompetensi Dasar Pelajaran pada Kurikulum 2013.

Pramana, C. (2020). Pembelajaran Pendidikan Anak Usia Dini (PAUD) di masa pandemi covid-19. Indonesian Journal of Early Childhood: Jurnal Dunia Anak Usia Dini, 2(2). DOI: 10.35473/ijec.v2i2.557

Purwanto, A., Pramono, R., Asbari, M., Santoso, P. B., Wijayanti, L. M., Hyun, C. C. \& Putri, R. S. (2020). Studi eksploratif dampak pandemi covid-19 terhadap proses pembelajaran online di sekolah dasar. Journal of Education, Psychology and Counseling, 2(1), 1-12. Retrieved from https://ummaspul.e-journal.id/Edupsycouns/article/view/397

Putria, H., Maula, L. H. \& Uswatun, D. A. (2020). Analisis proses pembelajaran dalam jaringan (daring) masa pandemi covid-19 pada guru sekolah dasar. Jurnal Basicedu, 4(4), 861-872.

Rasheed, R. A., Kamsin, A. \& Abdullah, N. A. (2019). Challenges in the online component of blended learning: A systematic review. Computers \& Education, 144. https://doi.org/10.1016/j.compedu.2019.103701

Rosali, E. S. (2020). Aktivitas pembelajaran daring pada masa pandemi covid-19 di jurusan pendidikan geografi Universitas Siliwangi Tasikmalaya. Geography Science Education Journal (GEOSEE), 1(1), 21-30.

Sadikin, A. \& Hamidah, A. (2020). Pembelajaran daring di tengah wabah covid-19. BIODIK: Jurnal Ilmiah Pendidikan Biologi, 06(02), 214-224. https://doi.org/10.22437/bio.v6i2.9759

Sudiana, R. (2016). Efektifitas penggunaan learning management system berbasis online. JPPM, 9(2), 201-209.

Sugiyono. (2014). Memahami penelitian kualitatif. Bandung: CV Alfabeta.

Suryadi, I., Suhartono \& Utomo, P. (2020). Pelaksanaan pembelajaran menulis teks ulasan siswa kelas VII SMP Negeri 17 Kota Bengkulu. Jurnal Ilmiah Korpus, 4(2). https://doi.org/10.33369/jik.v4i2.8334

Yuniar, M. S. \& Zuchdi, D. (2018). Pengembangan buku teks pembelajaran menulis teks nonsastra berbasis pendekatan proses. Jurnal Pendidikan Bahasa dan Sastra, 18(1), 106-113. https://doi.org/10.17509/bs_jpbsp.v18i1.12150

Zhang, Y., Jiang, B., Yuan, J. \& Tao, Y. (2020). The impact of social distancing and epicenter lockdown on the COVID-19 epidemic in mainland China: A data-driven SEIQR model study. MedRxiv. 